\title{
Correction to: The social geometry of collaborative flood risk management: a hydrosocial case study of Tillamook County, Oregon
}

\section{Melissa Haeffner ${ }^{1}$ (D) . Dana Hellman ${ }^{2}$}

Published online: 21 July 2020

(c) Springer Nature B.V. 2020

\section{Correction to: Natural Hazards https://doi.org/10.1007/s11069-020-04131-4}

The article was published informing readers: The SFC project cost nearly one million dollars, took years to complete, and emerged from a political stalemate. This is erroneous and should instead be noted as:

The SFC project cost over ten million dollars, took years to complete, and emerged from a political stalemate (Oregon Solutions, https://tillamookoregonsolutions.com/). This correction stands to correct the original article.

Publisher's Note Springer Nature remains neutral with regard to jurisdictional claims in published maps and institutional affiliations.

The original article can be found online at https://doi.org/10.1007/s11069-020-04131-4.

Melissa Haeffner melh32@pdx.edu

Dana Hellman dhellman@pdx.edu

1 Department of Environmental Science and Management, Portland State University, Portland, OR, USA

2 School of the Environment, Portland State University, Portland, OR, USA 